www.asianjournalofmycology.org Article

Doi 10.5943/ajom/2/1/17

\title{
Ceramothyrium chiangraiense, a novel species of Chaetothyriales (Eurotiomycetes) from Ficus sp. in Thailand
}

\author{
Wijesinghe $\mathrm{SN}^{1,2}$, Dayarathne $\mathrm{MC}^{1,2,3}$, Maharachchikumbura $\mathrm{SSN}^{4}$, Wanasinghe \\ $\mathrm{DN}^{3}$ and Hyde $\mathrm{KD}^{1,2,3}$
}

\author{
${ }^{1}$ Center of Excellence in Fungal Research, Mae Fah Luang University, Chiang Rai 57100, Thailand \\ ${ }^{2}$ School of Science, Mae Fah Luang University, Chiang Rai, 57100, Thailand \\ ${ }^{3}$ Key Laboratory for Plant Biodiversity and Biogeography of East Asia (KLPB), Kunming Institute of Botany, Chinese \\ Academy of Sciences, Kunming 650201, Yunnan, China \\ ${ }^{4}$ School of Life Science and Technology, University of Electronic Science and Technology of China, Chengdu, 611731, \\ People's Republic of China
}

Wijesinghe SN, Dayarathne MC, Maharachchikumbura SSN, Wanasinghe DN, Hyde KD 2019 Ceramothyrium chiangraiense, a novel species of Chaetothyriales (Eurotiomycetes) from Ficus sp. in Thailand. Asian Journal of Mycology 2(1), 269-280, Doi 10.5943/ajom/2/1/17

\begin{abstract}
In our investigation of epifoliar fungi, a novel species of Ceramothyrium; C. chiangraiense is isolated from the living leaves of Ficus sp. in Thailand. Genus Ceramothyrium is characterized by the ascomata covered with pellicle mycelium and the circumferential space around the maturing ascomata, bitunicate asci and phragmospores which lack setae. The new species resembles genus Ceramothyrium by its ascomata with superficial mycelial pellicle over the fruiting structures and scattered ascomata that cupulate when dry and 8-spored, bitunicate asci which contain hyaline, pluriseptate ascospores. We have processed the phylogeny based on Maximum Likelihood (ML) and Bayesian (BI) analyses using combined ITS and LSU sequence data. Based on phylogeny, C. chiangraiense is confirmed its placement within the genus Ceramothyrium and closely related to $C$. aquaticum, C. carniolicum, C. exiguum, C. linnaeae and C. phuquocense. Morphologically, C. chiangraiense is distinguished from phylogenetically related species (Ceramothyrium carniolicum, C. ficus, C. linnaeae, C. longivolcaniforme, C. menglunense, C. paiveae and C. thailandicum) by having obpyriform asci and 3-4 seriate, oblong to ellipsoid ascospores with 4-7 longitudinal and angled septa. An updated phylogenetic tree for the family Chaetothyriaceae (Eurotiomycetes) is constructed. The relationships of $C$. chiangraiense to other Ceramothyrium species are discussed based on comparative morphology and phylogenetic analyses.
\end{abstract}

Key words - new species - epifoliar fungi - morphology - phylogeny

\section{Introduction}

Order Chaetothyriales was introduced by Barr (1976) in Loculoascomycetes which are plant parasitic ascomycetes. Currently, the order is placed in the Eurotiomycetes based on the nucleotide data of 18s rDNA gene (Winka et al. 1998, Schoch et al. 2006). Members of Chaetothyriales are consisted of lichenized fungi, plant pathogens and opportunistic human and animal pathogens mostly in tropical and temperate ecosystems (Teixeira et al. 2017, Maharachchikumbura et al. 2018). 
The family Chaetothyriaceae was introduced by Hansford (1946) and it was considered to be the type family of the order Chaetothyriales by Batista \& Ciferri (1962). Members of the Chaetothyriaceae are superficially colonizing on leaf surfaces and form a dark, loose mycelium net on leaf surface (Chomnunti et al. 2012a). The mycelia are not penetrating in to the host tissues but appressed to the leaf cuticle (Batista \& Ciferri 1962, von Arx \& Müller 1975, Chomnunti et al. 2012a). They are also characterized by having ascomata with or without setae, and the ascomata are surrounded by a thin mycelial pellicle comprises a loose hyphal net looks like sooty molds which is covering the host surfaces between maturing ascomata (Hansford 1946, Batista \& Ciferri 1962, von Arx \& Müller 1975, Hughes 1976, Pereira et al. 2009, Chomnunti et al. 2012a, Yang et al. 2014, Zeng et al. 2016). Therefore, family Chaetothyriaceae was earlier classified as a capnodiaceous Dothideomycetes (Batista \& Ciferri 1962). Later, Eriksson (1982) placed Chaetothyriaceae in the order Dothideales. Finally, the family is accepted in Chaetothyriales by Barr (1987). Most of the Chaetothyriaceae species are reported as saprotrophic or biotrophic (Barr 1987, Chomnunti et al. 2012b, 2014, Hongsanan et al. 2016, Maharachchikumbura et al. 2018).

Wijayawardene et al. (2018) included 16 genera within Chaetothyriaceae and later, 17 genera are accepted by Crous et al. (2018). Chaetothyrium Speg. is accounted as the type genus of the family Chaetothyriaceae (Hughes 1976). The genus Ceramothyrium was introduced by Batista \& Maia (1956) in family Phaeosaccardinulaceae with C. paiveae as the type species. Hughes (1976) accepted the genus in family Chaetothyriaceae based on morphological evidences. Ceramothyrium is characterized by ascomata cover with pellicle mycelium and the circumferential space around the maturing ascomata, lack of setae, olivaceous to fuscous and hyaline to subhyaline or strawcoloured hyphae, bitunicate, 8-spored asci and hyaline, transversely pluriseptate ascospores (Batista \& Maia 1956, Hughes 1976, Chomnunti et al. 2012a, Zeng et al. 2016). Constantinescu et al. (1989) stated that the genus Ceramothyrium has hyphomycetous Stanhughesia asexual morphs. The asexual morphs of Ceramothyrium carniolicum (= Stanhughesia carniolica), C. linnaeae (= S. linnaeae) and $C$. lycopodii (= S. lycopodii) are obtained from pure cultures (Constantinescu et al. 1989). Crous et al. (2012) introduced the novel asexual morphs of Ceramothyrium as C. melastoma and C. podocarpi. There are 38 species epithets listed under the genus Ceramothyrium (Index Fungorum 2019). However, sequence data are available only for 11 species in GenBank (Yang et al. 2018, Yen et al. 2018).

In this study, a novel foliar epiphyte, Ceramothyrium chiangraiense is introduced from fresh and healthy leaves of Ficus sp. in Northern Thailand. Illustrations, comprehensive morphological descriptions and DNA analyses based on ITS and LSU sequence data are provided for the novel species.

\section{Materials \& Methods}

\section{Specimen collection, isolation and identification}

The fresh leaves with black spots on the surface were collected from Ficus sp. in Mae Fah Luang University premises at the end of the dry season (May 2018). Samples were taken to the laboratory inside the paper envelopes. Photographs of enlarged host leaves and ascomata were taken under a Motic SMZ 168 compound stereomicroscope. Morphological characters were examined by hand sectioning of fruiting bodies on the upper leaf surface. The micro-morphological structures of ascomata were photographed using a Nikon ECLIPSE 80i compound stereo microscope fitted with a Canon 600D digital camera. All structures (ascomata, asci and ascospores) were processed for photographs by immersing sections in water mounted clean glass slides. In the observation of asci and apical rings, $10 \% \mathrm{KOH}$ and Congo red were used when necessary. Following morphological characters were observed: ascomata-diameter, height, colour and shape; peridium-width; asci and ascospores-length and width (at the longest and widest point) and pseudoparaphyses-width. The measurements of photomicrograph structures were measured using Tarosoft (R) Image Frame Work version 0.9.7. program. Images used for figures were processed with Adobe Photoshop CS6 Extended version 13.0.1 software (Adobe Systems, USA). 
Single spore isolation technique was carried out to isolate fungal species present on the leaf surface. An ascoma was picked out on the host surface and it was immersed in $300 \mu$ of sterilized distilled water on a center curved glass slide and crushed using a sterilized needle until an ascospore suspension is obtained. Small drops of the spore suspension were placed on potato dextrose agar (PDA) media plates. Petri-plates were kept at $25{ }^{\circ} \mathrm{C}$ for $12-24 \mathrm{~h}$ for the ascospores germination. Single germinated ascospores aseptically transferred onto potato dextrose agar (PDA) plates. The plates were incubated at $25{ }^{\circ} \mathrm{C}$ for 15 to 20 days for pure cultures. Colony characters were observed and measured weekly. After a month, well-grown cultures were used to extract DNA. The holotype and isotype materials were deposited at Mae Fah Luang University herbarium (MFLU) in Chiang Rai, Thailand and Herbarium of Mycology, Chinese Academy of Sciences (HMAS) in China respectively. The ex-type cultures were deposited at Mae Fah Luang culture collection (MFLUCC). Facesoffungi number was obtained and Index Fungorum number was registered (Jayasiri et al. 2015, Index Fungorum 2019).

\section{DNA isolation, PCR amplification and Sequencing}

Genomic DNA was extracted from the scraped fresh fungal mycelium grown on PDA media for 6 weeks at $25^{\circ} \mathrm{C}$ by using Biospin Fungus Genomic DNA extraction Kit - BSC14S1 (BioFlux, P.R. China) following the instructions of the manufacturer. Template DNA was stored at $4{ }^{\circ} \mathrm{C}$ for use in regular work and duplicated at $-20{ }^{\circ} \mathrm{C}$ for long-term storage. DNA sequence data were obtained from the sequences of two regions, the internal transcribed spacers (ITS) and large subunit (LSU). ITS region was amplified using the primers ITS5 and ITS4 (White et al. 1990) and LSU region was amplified using the primers LR0R and LR5 (Vilgalys \& Hester 1990, Rehner \& Samuels 1994).

Polymerase chain reaction (PCR) was carried out in a final volume of $25 \mu$ which contained $12.5 \mu$ of $2 \times$ Power Taq PCR MasterMix (Bioteke Co., China), 20 mM Tris-HCL pH 8.3, $100 \mathrm{mM}$ $\mathrm{KCl}, 3 \mathrm{mM} \mathrm{MgCl} 2$ (for stabilizing and enhancing), $1 \mu \mathrm{l}$ of each forward and reverse primers (10 $\mu \mathrm{M}), 1 \mu \mathrm{l}$ template genomic DNA, and $9.5 \mu 1$ deionized water. In PCR profile, the reactions for ITS and LSU regions were initialized with the denaturation at $95^{\circ} \mathrm{C}$ for 5 mins, followed by 35 thermal cycles of denaturation at $95{ }^{\circ} \mathrm{C}$ for $90 \mathrm{~s}$, annealing at $55^{\circ} \mathrm{C}$ for $90 \mathrm{~s}$, elongation at $72{ }^{\circ} \mathrm{C}$ for $1 \mathrm{~min}$, and final extension at $72{ }^{\circ} \mathrm{C}$ for $10 \mathrm{~min}$. Sequencing of the PCR amplicons was conducted using the same primers used for the amplification reactions. The PCR products were verified by staining with ethidium bromide on $1 \%$ agarose electrophoresis gels. The amplified PCR fragments were sent to a commercial sequencing provider (BGI, Ltd., Shenzhen, China).

\section{Molecular data analyzing}

Lasergene SeqMan Pro v.7 was used to obtain consensus sequences from sequences generated from forward and reverse primers. Contig sequences were analyzed with other sequences retrieved from GenBank. Sequences with high similarity indices were determined by BLAST search and the related literature (Liu et al. 2015, Zeng et al. 2016, Crous et al. 2018, Maharachchikumbura et al. 2018, Yang et al. 2018, Yen et al. 2018). Final alignment consists of the new taxa proposed in this study and sequences of Chaetothyriaceae downloaded from the GenBank representing genera Aphanophora, Camptophora, Ceramothyrium, Chaetothyrium, Cyphellophoriella, Nullicamyces, Phaeosaccardinula and Vonarxia (Table 1). The single and multiple (ITS and LSU) alignments of all reference sequences, were automatically generated with MAFFT v. 7 (http://mafft.cbrc.jp/alignment/server/index.html, Katoh \& Standley 2013, Katoh et al. 2017). BioEdit v. 7.0.5.2 software was used when manual improvement is needed (Hall 1999). The terminal ends and ambiguous regions of the alignment were deleted.

Phylogenetic analyses of both individual and combined data-sets were based on Maximum Likelihood (ML) and Bayesian (BI) analyses. In BI analysis, the sequence alignments were converted from FASTA into NEXUS file format (.nex) using ClustalX2 v.1.83 (Thompson et al. 1997). The NEXUS file was prepared for MrModeltest v. 2.2 after (Nylander 2004) performing in PAUP (Phylogenetic Analysis Using Parsimony) v. 4.0b10 (Swofford 2003) to estimate the best 
evolutionary model. For RAxML analysis (Randomized Accelerated Maximum Likelihood), the sequence alignments were converted from FASTA into PHYLIP (.phy) file format using ALTER (alignment transformation environment, http://www.sing-group.org/ALTER/) bioinformatics web tool (Glez-Peña et al. 2010). The evolutionary models for both BI and ML analysis were evaluated independently for each locus. MrModeltest v. 2.3 (Nylander 2004) was run under the AIC (Akaike Information Criterion) implemented in PAUP v. 4.0b10. The evaluated best-fit model was GTR + I $+\mathrm{G}$ for each locus in both BI and ML analyses.

ML trees were generated with RAxML-HPC2 on XSEDE (v. 8.2.10) tool (Stamatakis 2014) in the CIPRES Science Gateway platform (Miller et al. 2010). The optimal ML tree search was conducted with 1,000 separate runs. The nonparametric bootstrap iterations (Stamatakis et al. 2008) were run in 1,000 replicates with the using GTR $+\mathrm{I}+\mathrm{G}$ model of evolution. ML trees were generated with RAxML-HPC2 on XSEDE (v. 8.2.10) tool (Stamatakis 2014) in the CIPRES Science Gateway platform (Miller et al. 2010).

Table 1 Taxa used for molecular study and their GenBank numbers.

\begin{tabular}{|c|c|c|c|}
\hline \multirow[b]{2}{*}{ Species } & \multirow{2}{*}{ Strain/Voucher } & \multicolumn{2}{|c|}{ GenBank accessions } \\
\hline & & ITS & $\overline{\text { LSU }}$ \\
\hline Aphanophora eugeniae & CBS 124105 & F J839617 & F J839652 \\
\hline Brycekendrickomyces acaciae & CBS 124104 & FJ839606 & F J839641 \\
\hline Camptophora hylomeconis & CBS 113311 & EU035415 & EU035415 \\
\hline C. schimae & IFRDCC 2664 & MF285231 & MF285233 \\
\hline Ceramothyrium aquaticum & VTCC:F-1210 & LC360299 & LC360296 \\
\hline C. carniolicum & CBS 175.95 & KC455237 & KC455251 \\
\hline C. chiangraiense & MFLUCC 18-1354 & MN481190 & MN449441 \\
\hline C. linnaeae & CBS 742.94 & MH862502 & MH874144 \\
\hline C. exiguum & VTCC:F-1209 & LC360297 & LC360295 \\
\hline C. ficus & MFLUCC 15-0229 & KT588602 & KT588600 \\
\hline C. ficus & MFLUCC 15-0228 & KT588601 & KT588599 \\
\hline C. longivolcaniforme & MFLU 16-1306 & KР324929 & KP324931 \\
\hline C. melastoma & СРC 19837 & KC005771 & КС005793 \\
\hline C. menglunense & MFLU 16-1874 & KX524148 & KX524146 \\
\hline C. podocarpi & CPC 19826 & КС005773 & KC005795 \\
\hline C. phuquocense & VTCC:F-1206 & LC360298 & LC360294 \\
\hline C. thailandicum & MFLUCC 10-0008 & HQ895838 & HQ895835 \\
\hline Chaetothyrium agathis & MFLUCC 12-0113 & KP744437 & KP744480 \\
\hline C. brischoficola & MFLU(CC)10-0012 & HQ895839 & HQ895836 \\
\hline Cyphellophoriella pruni & СРС 25120 & KR611878 & _ \\
\hline Nullicamyces eucalypti & CPC 32942 & МH327807 & MH327843 \\
\hline $\begin{array}{l}\text { Phaeosaccardinula } \\
\text { dendrocalami }\end{array}$ & IFRDCC 2663 & KF667242 & KF667246 \\
\hline P. coffeicola & COF25 & MH345730 & MH345729 \\
\hline P. ficus & MFLU(CC)10-0009 & HQ895840 & HQ895837 \\
\hline P. multiseptata & IFRDCC 2639 & KF667241 & KF667244 \\
\hline Vonarxia vagans & CBS 123533 & F J839636 & F J839672 \\
\hline
\end{tabular}

* Newly generated sequence is indicated in blue-bold and type materials are in bold 
MrBayes v.3.0b4 (Ronquist \& Huelsenbeck 2003) was used to conduct the BI analyses to evaluate Bayesian posterior probabilities (PP) (Rannala \& Yang 1996, Zhaxybayeva \& Gogarten 2002). Markov chain Monte Carlo sampling (BMCMC) with GTR + I + G was used as the best fit model of evolution for PP. Six simultaneous Markov chains were run for 1,000,000 generations, and trees were sampled every $1000^{\text {th }}$ generation. The distribution of log-likelihood scores was examined to determine the stationary phase for each search and to decide if extra runs were required to achieve convergence, using the program Tracer 1.5 (Rambaut \& Drummond 2007). Phylograms were envisioned with FigTree v1.4.0 program (Rambaut 2012) and modified in Microsoft PowerPoint (2010). Sequences generated in this study were deposited in GenBank (Table 1).

\section{Results}

\section{Phylogenetic analyses}

Final combined LSU and ITS alignment was processed to resolve the species relationship in the Chaetothyriaceae (Fig. 1). The alignment comprised 26 strains including the outgroup taxon Brycekendrickomyces acaciae (CBS 124104) and the manually adjusted dataset is comprised 1467 characters including gaps (LSU: 823; ITS: 641). The tree topology of the ML analysis is similar to the BI analysis and not shown significant difference. Also, the tree topology is similar to previous analysis performed by Yang et al. (2018). Novel strain Ceramothyrium chiangraiense (MFLUCC 18-1354) is grouped within the genus Ceramothyrium and constitutes a moderately-supported clade (77\% ML/0.98 PP, Clade A, Fig. 1) that comprises C. aquaticum, C. carniolicum, C. exiguum, C. linnaeae and C. phuquocense.

The best sorting RAxML tree with the final ML optimization likelihood value of 9007.254229 is represented in Fig. 1. The matrix had 587 distinct alignment patterns, with 15.53\% undetermined characters or gaps. Estimated base frequencies were as follows: $\mathrm{A}=0.242155, \mathrm{C}=$ $0.241240, \mathrm{G}=0.281076, \mathrm{~T}=0.235529$; substitution rates $\mathrm{AC}=1.718900, \mathrm{AG}=2.557961, \mathrm{AT}=$ 2.201386, $\mathrm{CG}=0.990328$, CT 6.413590, GT $=1.000000$; gamma distribution shape parameter $\alpha=$ 0.209737. In BI analysis, first $10 \%$ of generated trees were discarded and remaining $90 \%$ of trees were used to calculate posterior probabilities of the majority rule consensus tree. There are twenty seven credible sets of trees are sampled and final average standard deviation of split frequencies $=$ 0.002 .

\section{Taxonomy}

Ceramothyrium chiangraiense Wijesinghe \& K.D. Hyde, sp. nov.

Fig. 2

Index Fungorum number: IF556793; Facesoffungi number: FoF01680

Etymology - In reference to the locality, Chiang Rai province, Thailand where the fungus was collected

Holotype - MFLU 19-1351

Epifoliar growing on the leaf surfaces of Ficus spp. Upper surface covers with dark mycelium. Mycelial pellicle 3.2-5.5 $\mu \mathrm{m}$ wide $(\overline{\mathrm{x}}=4.5 \mu \mathrm{m}, \mathrm{n}=15)$, elongated, subiculum-like, pale brown to hyaline, mostly narrow, septate, slightly constricted at septa, circumferential space between matured ascomata spreading to outwards from center, anastomose at ostiole with the hyphal network. Sexual morph: Ascomata 185-210 × 165-205 $\mu \mathrm{m}(\overline{\mathrm{x}}=195 \times 180 \mu \mathrm{m}, \mathrm{n}=10)$, superficial, solitary or scattered, coriaceous, covered by subiculum, blackish to greenish brown, setae absent, globose to subglobose, uniloculate, flattened or cupulate when dry, ostiolate. Ostiole central, minutely papillate, single. Peridium 18-60 $\mu \mathrm{m}(\overline{\mathrm{x}}=35 \mu \mathrm{m}, \mathrm{n}=20)$ widest at the sides, comprising several thick-walled cell layers, outer layer comprising dark brown to black, pseudoparenchymatous, cells of textura prismatica, innermost layer comprising light brown cells of textura angularis. Hamathecium comprising numerous, $2-5 \mu \mathrm{m}$ wide $(\overline{\mathrm{x}}=3 \mu \mathrm{m}, \mathrm{n}=15)$, filamentous, septate, hyaline pseudoparaphyses. Asci 35-60 × 25-35 $\mu \mathrm{m}(\overline{\mathrm{x}}=48 \times 29 \mu \mathrm{m}, \mathrm{n}=15)$, 
8-spored, bitunicate, obpyriform sessile or short pedicellate, mostly evanescent, minute ocular chamber, with an apical ring. Ascospores 20-30 × 5-9 $\mu \mathrm{m}(\overline{\mathrm{x}}=25 \times 7 \mu \mathrm{m}, \mathrm{n}=40)$, crowded, 3-4 seriate, hyaline, oblong-ellipsoid, 4-7 longitudinal septa that are sometimes angled, no transverse septa, slightly constricted at the septa, without a mucilaginous sheath, smooth-walled, germ tubes developing from numerous cells. Asexual morph: Undetermined.

Culture characteristics - Ascospores germinating on PDA within 24 hours, from single spore isolation. Colonies on PDA reaching 6-8 mm diam. after 14 days at $24{ }^{\circ} \mathrm{C}$, slow growing, circular, undulate, convex with papillate surface, black to dark grey in upper surface and completely blackish grey in lower surface, greenish pale grey at the outer edge in entire circle.

Known distribution - Northern Thailand

Material examined - Thailand, Chiang Rai Province, Mae Fah Luang University, Opposite side of the swimming pool, on living leaves of Ficus sp. (Moraceae), 21 May 2018, Wijesinghe SN, NN022 (MFLU 19-1351, holotype), (isotype, HMAS 290496). Ex-type living culture MFLUCC 18-1354.

GenBank numbers - ITS: MN481190 and LSU: MN449441

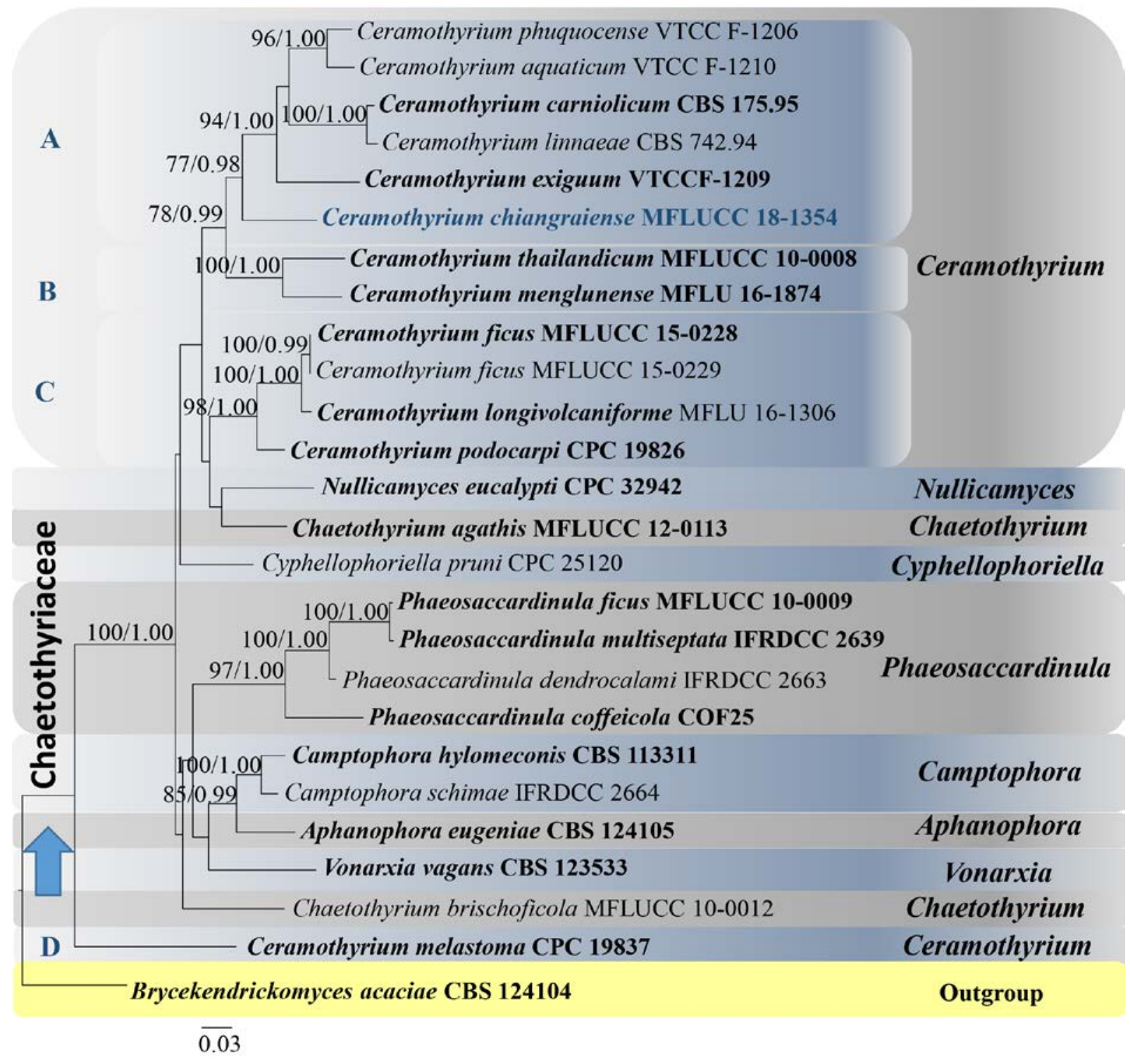

Fig. 1 - Phylogram generated from maximum likelihood analysis based on combined LSU and ITS sequence data for Chaetothyriaceae. ML $\geq 70 \%$ and $\mathrm{PP} \geq 0.95$ are given above each node. The tree is rooted to Brycekendrickomyces acaciae (CBS 124104). Novel species is visualized in blue-bold and type strains are symbolized in bold. 

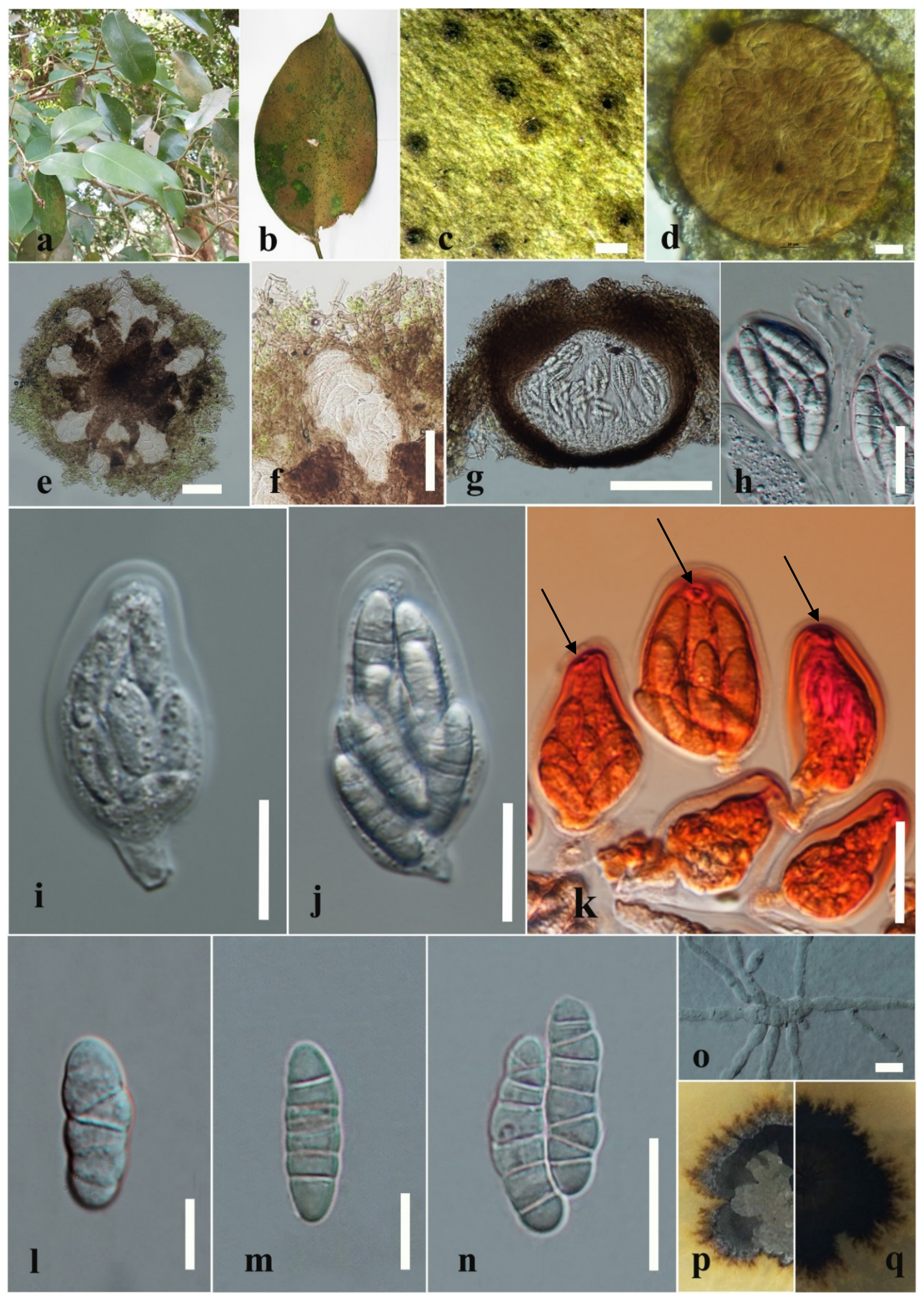

Fig. 2 - Ceramothyrium chiangraiense (MFLU 19-1351, holotype). a Host plant of Ficus sp. b, c Ascomata on living leaf surface. d, e Ascomata covered by a subiculum or layer. f Hyphae attaching to the margin of ascomata. g Longitudinal section of an ascoma with $10 \% \mathrm{KOH}$. h Pseudoaraphyses. i, j Asci. k Asci stained with Congo red (Arrows indicate apical rings). l-n Ascospores. o Germinated ascospore. p, q Colonies on PDA (p upper, q lower). Scale bars: $\mathrm{e}=$ $200 \mu \mathrm{m}, \mathrm{f}, \mathrm{g}, \mathrm{h}=100 \mu \mathrm{m}, \mathrm{d}, \mathrm{i}-\mathrm{k} \mathrm{n}, \mathrm{o}=20 \mu \mathrm{m}, \mathrm{l}, \mathrm{m}=10 \mu \mathrm{m}$. 


\section{Discussion}

Our multi-gene phylogenetic analysis (Fig. 1), indicates the new taxon is phylogenetically distinct to other taxa of Ceramothyrium (Clade A). The base pair similarities were analyzed for the taxa which show the close phylogenetic affinities to $C$. chiangraiense. Based on ITS sequence alignment $C$. chiangraiense has closest similarity to $C$. phuquocense (LC360298, Identities = 405/484 (83.67\%), 2 gaps (0.41\%)), to C. exiguum (LC360297, Identities = 411/496 (82.86\%), 14 gaps (2.82\%)), to C. aquaticum (LC360299, Identities = 405/489 (82.82\%), 7 gaps (1.43\%)), to C. linnaeae (MH862502, Identities $=426 / 545$ (78.16\%), 15 gaps $(2.75 \%)$ ) and to C. carniolicum $($ KC455237, Identities $=393 / 508$ (77.36\%), 13 gaps $(2.55 \%)$ ). Based on LSU sequence alignment the similarity of $C$. chiangraiense is closest to C. carniolicum (KC455251, Identities $=784 / 817$ (95.96\%), 3 gaps $(0.36 \%)$ ), to C. linnaeae (MH874144, Identities $=779 / 816(95.46 \%)$, 3 gaps $(0.36 \%)$ ), to C. phuquocense (LC360294, Identities $=501 / 527(95.06 \%), 6$ gaps $(1.13 \%)$ ), to $C$. aquaticum (LC360296, 495/525 (94.28\%), 7 gaps (1.33\%)) and to C. exiguum (LC360295, 493/527 (93.54\%), 6 gaps $(1.13 \%))$.

Species of the genus Ceramothyrium are separated into four major clades viz. A, B, C and D (Fig. 1). In clade A, new species Ceramothyrium chiangraiense forms a separate lineage sister to $C$. aquaticum, C. carniolicum, C. exiguum, C. linnaeae and C. phuquocense. Ceramothyrium chiangraiense is morphologically similar to taxa in genus Ceramothyrium, in having ascomata covered with a subiculum, circumferential space around matured ascomata, lack of setae, hyaline and transversely pluriseptate ascospores which are characteristic to the genus Ceramothyrium (Chomnunti et al. 2012a, Yen et al. 2018). The synopsis of morphological characters for the reported sexual morphs of Ceramothyrium species are presented in Table 2. Ceramothyrium chiangraiense is distinct from other Ceramothyrium species in having obpyriform asci, 3-4 seriate and oblong-ellipsoid ascospores with 4-7 transverse septa (without distinct pattern). Ceramothyrium carniolicum and C. linnaeae are morphologically and phylogenetically close to C. chiangraiense (Fig. 1). Ceramothyrium carniolicum, C. linnaeae and C. chiangraiense comprise epiphyllous, scattered, superficial and brownish black ascomata without setae which can be easily wiped when dried. The mycelial pellicle of them are formed in surrounding area of ascomata on upper host surface. Also, they have 8-spored, bitunicate asci with a deeply staining apical ring (k, Fig. 2) in Congo red (von Arx \& Müller 1975, Ainsworth et al. 2015) and multi-septate ascospores which are strongly or slightly constricted at the septa and lack gelatinous sheath. However, $C$. chiangraiense and C. carniolicum have moderately large ascomata, asci and ascospores than those of $C$. linnaeae (Table 2). Occasionally C. linnaeae has amphigenous ascomata (Sutton et al. 1990). Both $C$. carniolicum and C. linnaeae have mucronate (small pointed appendages at both apices) ascospores (Ainsworth et al. 2015), while pointed appendages are absent in ascospores of $C$. chiangraiense.

Clade B which consisted of C. menglunense and C. thailandicum is sister to clade A. Both species in clade B, have clavate to pyriform asci (Chomnunti et al. 2012a, Hyde et al. 2016) while C. chiangraiense has obpyriform asci. Also, ascospores of $C$. menglunense are muriform (Hyde et al. 2016) while ascospores of $C$. chiangraiense are phragmosporic. Also, C. menglunense differs from $C$. chiangraiense and other Ceramothyrium species by the presence of brown setae (Hyde et al. 2016). However, C. menglunense and C. chiangraiense both have an inner peridium of textura angularis but differ to each other from the outer layer of textura globulosa in $C$. menglunense and textura prismatica in $C$. chiangraiense. Ceramothyrium thailandicum can be distinguished from $C$. chiangraiense by the presence of mucilaginous sheath of ascospores (Chomnunti et al. 2012a) while $C$. chiangraiense do not have a sheath. However, the presence of the sheath may be changed according to maturity.

Clade C is represented Ceramothyrium ficus, C. longivolcaniforme and C. podocarpi. Ceramothyrium chiangraiense has a similar character to C. longivolcaniforme by having oblongellipsoid ascospores (Zeng et al. 2016). However, C. chiangraiense differs from C. ficus and C. longivolcaniforme through shape of asci, C. ficus has clavate asci and C. longivolcaniforme has clavate to pyriform or obovoid asci, while $C$. chiangraiense has obpyriform asci. Also, $C$. 
longivolcaniforme is similar to C. chiangraiense by having short pedicellate asci while C. ficus comprises long pedicellate asci (Hongsanan et al. 2015, Zeng et al. 2016).

Clade D is consisted of C. melastoma (CPC 19837). Only asexual morph is known for $C$. melastoma (Crous et al. 2012). The recent analysis performed by Yen et al. (2018) and Yang et al. (2018) excluded C. melastoma (CPC 19837) in their analysis. In present study, Chaetothyrium brischoficola (MFLUCC 10-0012) and C. agathis (MFLUCC 12-0113) are not form a stable clade within family Chaetothyriaceae (Fig. 1). This is probably, due to short LSU and ITS sequences of C. brischoficola. In the recent study done by Yang et al. (2018), these two species were shown this unstable placement.

Table 2 Synopsis of morphological characters of related sexual morphs of Ceramothyrium species to $C$. chiangraiense

\begin{tabular}{|c|c|c|c|c|c|c|c|}
\hline \multirow[b]{2}{*}{ Taxa } & \multirow[b]{2}{*}{$\begin{array}{l}\text { Ascomata } \\
(\mu \mathrm{m})\end{array}$} & \multirow[b]{2}{*}{$\begin{array}{l}\text { Asci } \\
(\mu \mathrm{m})\end{array}$} & \multicolumn{4}{|c|}{ Ascospores } & \multirow[b]{2}{*}{ Reference } \\
\hline & & & $\operatorname{Size}(\mu \mathrm{m})$ & Shape & Septation & $\begin{array}{l}\text { Arrangeme } \\
\text { nt }\end{array}$ & \\
\hline $\begin{array}{l}\text { Ceramothyrium } \\
\text { chiangraiense }\end{array}$ & $\begin{array}{l}185-210 \times \\
165-205\end{array}$ & $\begin{array}{l}35-60 \times \\
25-35\end{array}$ & $\begin{array}{l}20-31 \times \\
5-9\end{array}$ & $\begin{array}{l}\text { Oblong- } \\
\text { ellipsoid }\end{array}$ & $\begin{array}{l}4-7 \\
\text { longitudinal } \\
\text { septa }\end{array}$ & 3-4 seriate & This study \\
\hline C. carniolicum & $150-200$ & $40 \times 20$ & $\begin{array}{l}18-26 \times \\
4-6\end{array}$ & $\begin{array}{l}\text { Oblong- } \\
\text { fusiform, } \\
\text { mucronate }\end{array}$ & 3 septate & - & $\begin{array}{l}\text { Petrak (1961), } \\
\text { Sutton et al. } \\
\text { (1990), } \\
\text { Ainsworth et al. } \\
\text { (2015), Zeng et } \\
\text { al. (2016) }\end{array}$ \\
\hline C. ficus & $\begin{array}{l}475-550 \times \\
120-130\end{array}$ & $\begin{array}{l}95-110 \\
\times 30-39\end{array}$ & $\begin{array}{l}36-39 \times \\
7-8\end{array}$ & $\begin{array}{l}\text { Sub- } \\
\text { cylindrical }\end{array}$ & $\begin{array}{l}7-8 \\
\text { transversal, } \\
1 \\
\text { longitudinal } \\
\text { septum }\end{array}$ & 3-5 seriate & $\begin{array}{l}\text { Hongsanan et } \\
\text { al. (2015) }\end{array}$ \\
\hline C. linnaeae & 90-120 & $\begin{array}{l}25-30 \times \\
12-15\end{array}$ & $\begin{array}{l}14-19 \times \\
3-5\end{array}$ & $\begin{array}{l}\text { Fusoid, } \\
\text { mucronate }\end{array}$ & $\begin{array}{l}3 \text { septate } \\
-\end{array}$ & 4-5 seriate & $\begin{array}{l}\text { Batista \& } \\
\text { Ciferri (1963), } \\
\text { Hughes (1976), } \\
\text { Sutton et al. } \\
\text { (1990), } \\
\text { Ainsworth et al. } \\
\text { (2015), Zeng et } \\
\text { al. (2016) }\end{array}$ \\
\hline $\begin{array}{l}\text { C. } \\
\text { longivolcanifor } \\
\text { me }\end{array}$ & 650-900 & $\begin{array}{l}67-90 \times \\
27-45\end{array}$ & $\begin{array}{l}28-37 \times \\
7-13\end{array}$ & $\begin{array}{l}\text { Oblong to } \\
\text { ellipsoid }\end{array}$ & $\begin{array}{l}7 \\
\text { transversals, } \\
6 \\
\text { longitudinal } \\
\text { septa } \\
4-7\end{array}$ & 2 seriate & $\begin{array}{l}\text { Zeng et al. } \\
\text { (2016) }\end{array}$ \\
\hline C. menglunense & $\begin{array}{l}245-255 \times \\
140-165\end{array}$ & $\begin{array}{l}50-75 \times \\
24-30\end{array}$ & $\begin{array}{l}25-35 \times \\
10-12\end{array}$ & $\begin{array}{l}\text { Ellipsoid } \\
\text { to obovoid }\end{array}$ & $\begin{array}{l}\text { transversal, } \\
1-5 \\
\text { longitudinal } \\
\text { septa }\end{array}$ & 2-3 seriate & $\begin{array}{l}\text { Hyde et al. } \\
\text { (2016) }\end{array}$ \\
\hline C. paiveae & - & - & $\begin{array}{l}12.5-22 \\
\times 3.7-6\end{array}$ & - & 1-4 septate & - & $\begin{array}{l}\text { Batista \& Maia } \\
\text { (1956), Zeng et } \\
\text { al. (2016) }\end{array}$ \\
\hline C. thailandicum & $\begin{array}{l}200-255 \times \\
100-160\end{array}$ & $\begin{array}{l}70-96 \times \\
39-53\end{array}$ & $\begin{array}{l}24.7- \\
35.5 \times \\
5.7-8.7\end{array}$ & $\begin{array}{l}\text { Cylindro- } \\
\text { clavate }\end{array}$ & $\begin{array}{l}7-9 \\
\text { transversal } \\
\text { septa }\end{array}$ & 3-5-seriate & $\begin{array}{l}\text { Chomnunti et } \\
\text { al. (2012a) }\end{array}$ \\
\hline
\end{tabular}

“_”: no information 
In most recent studies above gene regions have been used for the phylogenetic analysis of family Chaetothyriaceae (Hongsanan et al. 2015, Zeng et al. 2016, Yang et al. 2018, Yen et al. 2018). Thus, we used combined LSU and ITS regions for the identification of species boundaries in genus Ceramothyrium. It is estimated that the genus Ceramothyrium includes 38 species (Yen et al. 2018). Considering the asexual morphs of this genus, stanhughesia-like asexual morphs are reported for Ceramothyrium aquaticum, C. exiguum and C. phuquocense from submerged decaying leaves in Vietnam (Yen et al. 2018). However, we could not observe the asexual morph of our new species. However, in the future if we can obtain the asexual morph of $C$. chiangraiense we will introduce more samples to stabilize its taxonomic placement and the reference sequences to GenBank.

\section{Acknowledgements}

We are grateful to the Mushroom Research Foundation (MRF). Dhanushka Wanasinghe would like to thank CAS President's International Fellowship Initiative (PIFI) for funding his postdoctoral research (number 2019PC0008), the National Science Foundation of China and the Chinese Academy of Sciences for financial support under the following grants: 41761144055, 41771063 and Y4ZK111B01. Monika Dayarathne would like to acknowledge the projects, viz. National Natural Science Foundation of China (No. 31560489, 31972222), Science and technology basic work of MOST [2014FY120100], National Key Technology Research and Development Program of the Ministry of Science and Technology of China (2014BAD23B03/03), Talent project of Guizhou science and technology cooperation platform ([2017]5788-5, [2019]5641) and Guizhou science, technology department international cooperation base project ([2018]5806). SN Wijesinghe offers her deepest gratitude to Dr. Samantha C. Karunarathne, Dr. Udeni Jayalal, Vinodhini Thiyagaraja and Achala Rathnayaka for their precious assistance during this study.

\section{References}

Ainsworth AM, Taylor S, Cannon PF. 2015 - Following in the footsteps of Dickie and Leighton: some rarely recorded microfungi on Twinflower leaves including Ceramothyrium linnaeae, new to Britain. Field Mycology 16, 5-11.

Barr ME. 1976 - Perspectives in the Ascomycotina. Memoirs of the New York Botanical Garden 28, 1-8.

Barr ME. 1987 - Prodromus to class Loculoascomycetes. Publ. by the author. Amherst, Massachusett.

Batista AC, Ciferri R. 1962 - The Chaetothyriales. Beihefte zur Sydowia 3, 1-129.

Batista AC, Ciferri R. 1963- Capnodiales. Saccardoa, Monographiae Mycologicae 2, 1-299.

Batista AC, Maia HS. 1956 - Ceramothyrium a New Genus of the Family Phaeosaccardinulaceae. Atti dell'Istituto Botanico della Universita e Laboratorio Crittogamico di Pavia 14, 23-52.

Chomnunti P, Bhat DJ, Jones EGB, Chukeatirote E et al. 2012b - Trichomeriaceae, a new sooty mould family of Chaetothyriales. Fungal Diversity 56, 63-76.

Chomnunti P, Hongsanan S, Aguirre-Hudson B, Tian Q et al. 2014 - The sooty moulds. Fungal Diversity 66, 1-36.

Chomnunti P, Ko TWK, Chukeatirote E, Hyde KD et al. 2012a - Phylogeny of Chaetothyriaceae in northern Thailand including three new species. Mycologia 104, 382-395.

Constantinescu O, Holm K, Holm L. 1989 - Teleomorph-Anamorph Connections in Ascomycetes. 1-3. Stanhughesia (Hyphomycetes) New Genus, the Anamorph of Ceramothyrium. Studies in Mycology 31, 69-84.

Crous PW, Shivas RG, Wingfield MJ, Summerell BA et al. 2012 - Fungal Planet description sheets: 128-153. Persoonia: Molecular Phylogeny and Evolution of Fungi 29, 146 -201.

Crous PW, Wingfield MJ, Burgess TI, Hardy GSJ et al. 2018 - Fungal Planet description sheets: 716-784. Persoonia: Molecular Phylogeny and Evolution of Fungi 40, 240-393. 
Eriksson OE. 1982 - Notes on ascomycete systematics. Systema Ascomycetum 11, 49-82.

Glez-Peña D, Gómez-Blanco D, Reboiro-Jato M, Fdez-Riverola F et al. 2010 - ALTER: programoriented conversion of DNA and protein alignments. Nucleic Acids Research 38, 14 18.

Hall TA. 1999 - BioEdit: A user-friendly biological sequence alignment editor and analysis program for Windows 95/98/NT. Nucleic Acids Symposium Series 1, 95-98.

Hansford CG. 1946 - The foliicolous ascomycetes, their parasites and associated fungi. Mycological Papers 15, 1-240.

Hongsanan S, Hyde KD, Bahkali AH, Camporesi E et al. 2015 - Fungal biodiversity profiles 1120. Cryptogamie, Mycologie 36, 355-381.

Hongsanan S, Tian Q, Hyde KD, Hu DM. 2016 - The asexual morph of Trichomerium gloeosporum. Mycosphere 7, 1473-1479.

Hughes SJ. 1976 - Sooty moulds. Mycologia 68, 693-820.

Hyde KD, Hongsanan S, Jeewon R, Bhat DJ et al. 2016 - Fungal diversity notes 367-490: taxonomic and phylogenetic contributions to fungal taxa. Fungal Diversity 80, 1-270.

Index Fungorum. 2019 - http://www.indexfungorum.org/Names/Names.asp. (Accessed: October 2019).

Jayasiri SC, Hyde KD, Ariyawansa HA, Bhat DJ et al. 2015 - The Faces of Fungi database: fungal names linked with morphology, phylogeny and human impacts. Fungal Diversity 74, 3-18.

Katoh K, Rozewicki J, Yamada KD. 2017 - MAFFT online service: multiple sequence alignment, interactive sequence choice and visualization. Briefings in Bioinformatics, bbx108.

Katoh K, Standley DM. 2013 - MAFFT multiple sequence alignment software version 7: improvements in performance and usability. Molecular Biology and Evolution 30, 772-780.

Liu XY, Udayanga D, Luo ZL, Chen LJ et al. 2015 - Backbone tree for Chaetothyriales with four new species of Minimelanolocus from aquatic habitats. Fungal Biology 11, 1046-1062.

MAFFT version 7. 2019 - https://mafft.cbrc.jp/alignment/server, (Accessed October 2019).

Maharachchikumbura SSN, Haituk S, Pakdeeniti P, Al-Sadi AM et al. 2018 - Phaeosaccardinula coffeicola and Trichomerium chiangmaiensis, two new species of Chaetothyriales (Eurotiomycetes) from Thailand. Mycosphere 9, 769-778.

Miller MA, Pfeiffer W, Schwartz T. 2010 - Creating the CIPRES Science Gateway for inference of large phylogenetic trees. In: In: Proceedings of the gateway computing environments workshop (GCE) 14 Nov 2010. Institute of Electrical and Electronics Engineers, New Orleans, LA, pp 1-8.

Nylander JAA. 2004 - MrModeltest 2.0. Program distributed by the author. Evolutionary Biology Centre, Uppsala University.

Pereira RC, Dornelo-Silva D, Inacio CA, Dianese JC. 2009 - Chaetothyriomyces: a new genus in family Chaetothyriaceae. Mycotaxon 107, 484-488.

Petrak F. 1961 - Mykologische Bemerkungen. Sydowia 15, 204-217.

Rambaut A, Drummond AJ. 2007 - Tracer v1, 4. Available from: http://beast.bio.ed.ac.uk/Tracer.

Rambaut A. 2012 - FigTree v. 1.4.0. Available at http://tree.bio.ed.ac.uk/ software/figtree/

Rannala B, Yang Z. 1996 - Probability distribution of molecular evolutionary trees: a new method of phylogenetic inference. Journal of Molecular Evolution 43, 304-311.

Rehner SA, Samuels GJ. 1994 - Taxonomy and phylogeny of Gliocladium analyzed from nuclear large subunit ribosomal DNA sequences. Mycological Research 98, 625-634.

Ronquist F, Huelsenbeck JP. 2003 - MrBayes 3: Bayesian phylogenetic inference under mixed models. Bioinformatics 19, 1572-1574.

Schoch CL, Shoemaker RA, Seifert Hambleton KA, Spatafora JW et al. 2006 - A multigene phylogeny of the dothideomycetes using four nucler loci. Mycologia 98, 1043-1054.

Stamatakis A, Hoover P, Rougemont J. 2008 - A rapid bootstrap algorithm for the RAxML web servers. Systematic Biology 57, 758-771.

Stamatakis A. 2014 - RAxML version 8: a tool for phylogenetic analysis and post-analysis of large phylogenies. Bioinformatics 30, 1312-1313. 
Sutton BC. 1990 - "Memorial Issue Dedicated to JA von Arx, HA van der Aa, W. Gams, GS de Hoog, RA Samson (Eds.) Studies in Mycology, 31 (1989), p. 212, Price Hfl. 95.” Mycological Research 94, 431.

Swofford DL. 2003 - PAUP* 4.0b10: phylogenetic analysis using parsimony (*and other methods). Sinauer Associates, Sunderland, Massachusetts.

Teixeira MDM, Moreno LF, Stielow BJ, Muszewska A et al. 2017 - Exploring the genomic diversity of black yeasts and relatives (Chaetothyriales, Ascomycota). Studies in Mycology 86, 1-28.

Thompson JD, Gibson TJ, Plewniak F, Jeanmougin F et al. 1997 - The CLUSTAL_X windows interface: flexible strategies for multiple sequence alignment aided by quality analysis tools. Nucleic acids research 25, 4876-4882.

Vilgalys R, Hester M. 1990 - Rapid genetic identification and mapping of enzymatically amplified ribosomal DNA from several Cryptococcus species. Journal of Bacteriology 172, 4238-4246.

von Arx JA, Müller E. 1975 - A re-evaluation of the bitunicate ascomycetes with keys to families and genera. Studies in Mycology 9, 1-159.

White TJ, Bruns T, Lee S, Taylor J. 1990 - Amplification and direct sequencing of fungal ribosomal RNA genes for phylogenies. In: Innis MA, Gelfand DH, Sninsky JJ, White TJ (eds) PCR protocols: a guide to methods and applications. Academic Press, San Diego, pp 315-322.

Winka K, Eriksson OE, Bang A. 1998 - Molecular evidence for recognizing the Chaetothyriales. Mycologia 90, 822-830.

Wijayawardene NN, Hyde KD, Lumbsch HT, Liu JK et al. 2018 - Outline of Ascomycota: 2017. Fungal Diversity 88, 167-263.

Yang H, Chomnunti P, Ariyawansa HA, Wu HX et al. 2014 - The genus Phaeosaccardinula (Chaetothyriales) from Yunnan, China, introducing two new species. Chaing Mai Journal of Science 41, 873-884.

Yang H, Hyde KD, Karunarathna SC, Deng C et al. 2018 - New species of Camptophora and Cyphellophora from China, and first report of sexual morphs for these genera. Phytotaxa, 343, 149-159.

Yen LTH, Tsurumi Y, Hop DV, Ando K. 2018 - Three New Anamorph of Ceramothyrium from Fallen Leaves in Vietnam. Advances in Microbiology 8, 314-323.

Zeng XY, Wen TC, Chomnunti PR, Liu JK et al. 2016 - Ceramothyrium longivolcaniforme sp nov., a new species of Chaetothyriaceae from northern Thailand.

Zhaxybayeva O, Gogarten JP. 2002 - Bootstrap, Bayesian probability and maximum likelihood mapping: exploring new tools for comparative genome analyses. BMC Genomics 3, 4. 